\title{
GRAIN YIELD LOSSES OF SOME WHEAT GENOTYPES TO STRIPE RUST IN EGYPT
}

\author{
M. A. Ashmawy ${ }^{(1)}$ and Kh. E. Ragab ${ }^{(2)}$ \\ (1) Wheat Diseases Research Department, Plant Pathology Research Institute, ARC Giza. \\ (2) Wheat Research Department, Field Crops Research, ARC, Giza Egypt. \\ Email: dr_ashmawy2011@yahoo.com
}

Received: Mar.8, 2016

Accepted: Jun.1, 2016

\begin{abstract}
Stripe rust, caused by Puccinia striifarmis f. sp. tritici is an dangerous disease of wheat worldwide. To estimate grain yield losses due to stripe rust, replicated experiments including forty wheat genotypes i.e. Gemmeiza 9, Gemmeiza 11, Sakha 61, Sakha 69, Sakha 93, Sakha 94, Sids 12, Sids 13, Misr 1, Misr 2, Giza 168, Giza 171, Shandweel 1 and Morocco were evaluated for adult plant resistance at Sakha Research Station, Kafr El-Sheikh, Egypt during 2013/14 and 2014/15 growing seasons. The field experiment was surrounded by spreader area of highly susceptible genotypes i.e. Triticum spelta saharences inoculated with a mixture of stripe rust races as a source of inoculum. In general, the rust severity of wheat genotypes was higher at second season than that at first season. Disease severity was recorded each 10 days (5MR to 80S) the first season (10MR to 90S) the second season. Area under disease progress curve (AUDPC) was estimated and ranged from26 to 1750 in 2013/14 and 26 to 2050 in 2014/15. It was found that, yield losses ranged between $3.86 \%$ in the wheat genotypes Shandaweel 1 to $31.17 \%$ in the wheat genotypes Morocco during 2013/14, while during 2014/15 ranged from $3.86 \%$ in the wheat cultivar Misr 2 to $37.39 \%$ in the wheat cultivar Morocco. Concerning yield losses in 1000-kernel weight, the genotype Sakha 61 recording less value $2.6 \%$ white Morocco was higher value $30.49 \%$ and $32.74 \%$ in two growing seasons. High correlation was found between yield losses with disease severity and AUDPC.
\end{abstract}

Key words:Wheat, Puccinia striifarmis, resistance, susceptibility, yields losses.

\section{INTRODUCTION}

Stripe rust of wheat caused by Puccinia striifarmis f. sp. tritici can be as damaging as stem rust. However, stripe rust has a lower optimum temperature for development that limits it as a major disease in many areas of the world. Stripe rust is principally an important disease of wheat during winter or early spring or al high elevation. Roelfs etal (1992). Grain losses caused by this devastating pathogen have been reported from 10-70 percent Chen and Penman,(2005).

The frequency of epidemics and damage caused by stripe rust is different in each country. In Egypt stripe rust is the most common and important wheat disease, it caused severe losses in grain yield Abu ElNaga, et. al. (1998 and 2001). Man's methods are available to control wheat rusts. One of them, the economical and environmentally safe protection of wheat against rusts is possible by growing resistant relative humidity are the suitable factors to the wide distribution of the disease Stubbs, (1988); Johnson, (1988) and Denial, (1994).

In Egypt it is a sporadic disease because it appears in some years and diaspor in other years. Yellow rust disease in Egypt was appeared in 1990's it became familiar due to its continuous appearance. Abu ElNaga, et. al., (2001). Screening of genotypes against stripe rust is a regular activity due to the dynamic nature of the pathogen. This pathogen produces new 
races quickly through mutation and somatic hybridization Stubbs, (1985). Local yellow rust races can migrate to other areas and quickly become regionally and often globally predominant. Virulence for certain gene(s) combinations may still be absent regionally Singh et. al., (2002). The disease was recognized as epidemic in 1967 on the wheat genotypes Giza 144 at Manzala district, 1996 and 1997 on Sakha 69, Giza 163, Gemmeiza 1 and most of the commercial genotypes especially the long spiked ones, at the northern governorates during 2000 growing season Abd el- Hak, et. al., 1972; El- Daoudi, et. al., 1996 and Abu El- Naga,et. al., 1998, 1999, and 2001.

Seedling resistance is usually race specific and can be recognized by its characteristic resistance type at all plant stages Hong and Singh (1996). Adult plant resistance can be either specific or race non- specific and it usually better recognized after the seedling stage (Jonhson, 1988).

The objectives of this study were evaluated of some Egyptian wheat genotypes against stripe rust. Also, to estimate yield losses in grain yield these varieties against stripe rust.

\section{MATERALS AND METHODS}

This experiment was carried out at Sakha Agricultural Research Station in two successive growing seasons i.e. 2013/14 and $2014 / 15$, using 14 wheat genotypes i.e. Gemmeiza 9, Gemmeiza 11, Sakha 61, Sakha 69, Sakha 93, Sakha 94, Sids 12, Sids 13, Misr 1, Misr 2 Giza 168, Giza 171, Shandweel 1 and Morocco (as a check variety) Table 1 . The wheat varieties were arranged in a randomized complete block design $(R C B)$ with three replicates. The plot size was $6 \times 7 \mathrm{~m}$; each plot contained 20 rows with $7 \mathrm{~m}$ long and $30 \mathrm{~cm}$ between rows. The experiment was planted 15 days after the regular sowing date (the first half of December) to expose the plants to suitable environment of yellow rust incidence and development. Plots were surrounded by spreader area planted with a mixture of highly susceptible wheat genotypes to stripe rust i.e. Triticum spelta saharences to spread inoculums. To provide and maintain the rust inoculum pressure, the experiment was also artificially inoculated at the first week of February. To maintain crop stand and vigor, normal agronomic practices including recommended fertilization dose and irrigation schedule were followed. To keep protected plots almost free from stripe rust, the fungicide Sumi-eight 5EC $(1 \mathrm{H}-1,2$, 4-Triazole-1-ethanol,beta.-[(2,4-

dichlorophenyl)methylene]-.alpha.(1,1dimethylethyl)-,(.beta.E) (35 cm /100 litter water) was applied at 10 days.

Stripe rust severity and reaction were scored for each plot every 10 days intervals from rust appearance along with the stages of plant growth using the modified Cob's scale Peterson, et al., (1948) and the host response scale described by Roelfs, et al., (1992).

The area under disease progress curve (AUDPC) was calculated for each variety according to the equation adopted by Pandy, et. al., (1989).

$A U D P C=D[1 / 2(Y 1+Y k)+(Y 2+Y 3+\cdots$ - - + Yk-1)]

Where: $D=$ days between two consecutive records (time intervals)

$\mathrm{Y} 1+\mathrm{Yk}=$ Sum of the first and last disease records.

$\mathrm{Y} 2+\mathrm{Y} 3+\cdots+-\mathrm{Yk}^{-1}=$ Sum of all in between disease

At maturity the crop was harvested and yield of each genotype of $42 \mathrm{~m}^{2}$ was weighed by conventional balance. The influence of stripe rust severities on yield was determined by comparing the yield of infected and protected cultivars. Yield loss was estimated using the simple equation as follows:-

Loss \% = 1-Yd/Yh X 100 (Colpauzos, et al., 1976).

Where: $Y d=$ Yield of diseased plants.

$\mathrm{Yh}=$ Yield of healthy plants. 
Table 1: List of the local bread wheat genotypes that were used, pedigree and year of release

\begin{tabular}{|c|c|c|c|}
\hline No. & Genotype & Designation & $\begin{array}{c}\text { Year } \\
\text { of release }\end{array}$ \\
\hline 1 & Gemmeiza 9 & ALD"S"/HUAC"S"//CMH74A.630/SX. GM4583-5GM-1GM-0GM. & 1999 \\
\hline 2 & Gemmeiza 11 & $\begin{array}{l}\text { B0W"S"/KVZ"S"//7C/SERI82/3/GIZA168/SAKHA61.GGM7892- } \\
\text { 2GM-1GM-2GM-1GM-0GM. }\end{array}$ & 2011 \\
\hline 3 & Sakha 61 & INIA/RL4220//7C/YR"S"CM15430-2S-5S-0S-0S & 1980 \\
\hline 4 & Sakha 69 & INIA/RL4220//7C/YR"S"CM15430-2S-6S-0S-0S & 1980 \\
\hline 5 & Sakha 93 & Sakha 92/TR 810328 S 8871-1S-2S-1S-0S & 1999 \\
\hline 6 & Sakha 94 & $\begin{array}{l}\text { OPATA/RAYON//KAUZ.CMBW90Y3280-0TOPM-3Y-010M-010M- } \\
\text { 010Y-10M-015Y-0Y-0AP-0S. }\end{array}$ & 2004 \\
\hline 7 & Sids 12 & $\begin{array}{l}\text { BUC//7C/ALD/5/MAYA74/ON//1160-147/3/BB/GLL/4/ } \\
\text { CHAT"S"/6/MAYA/VUL//CMH74A.630/4*SX.SD7096-4SD-1SD- } \\
\text { 1SD-0SD. }\end{array}$ & 2007 \\
\hline 8 & Sids 13 & $\begin{array}{l}\text { KAUZ "S"//TSI/SNB"S". ICW94-0375-4AP-2AP-030AP -0APS- } \\
\text { 3AP-0APS-050AP-0AP-0SD. }\end{array}$ & 2010 \\
\hline 9 & Misr 1 & $\begin{array}{l}\text { OASIS/SKAUZ//4*BCN/3/2*PASTOR.CCMSSOYO1881T-050M- } \\
\text { 030Y-O3OM-030WGY-33M-0Y-0S. }\end{array}$ & 2011 \\
\hline 10 & Misr 2 & $\begin{array}{l}\text { SKAUZ/BAV92. CMSS96M0361S-1M-010SY-010M-010SY-8M- } \\
\text { OY-0S. }\end{array}$ & 2011 \\
\hline 11 & Giza 168 & MIL/BUC//Seri CM93046-8M-0Y-0M-2Y-0B & 1999 \\
\hline 12 & Giza 171 & Sakha93/Gemmeiza9 S6-1GZ-2GZ-2GZ-OS & 2012 \\
\hline 13 & Shandaweel 1 & SITE/MO/4/NAC//*PVN/3/MiRLO & 2012 \\
\hline
\end{tabular}

Data of 1000-kernel weight $(\mathrm{g})$ and grain yield $(\mathrm{kg})$ was calculated according Hassan (2004). Randomly selected thousand kernels from each genotype were counted with a seed counter and were weighed with an electronic balance to calculate 1000kernel weight. The grain weight from the threshed spikes was measured entire harvested plots was weighed with an electronic balance to calculate grain yield per plot for each genotype.

Least significant differences (L.S.D. at $5 \%$ were used to compare yield components according to Snedecor, (1957). Correlation coefficient was also used to detect the relationship between yield loss and AUDPC.

\section{RESULTS AND DISCUSSION}

The present study clearly showed that the wheat genotypes showed high stripe rust disease severity were exhibited maximum values of AUDPC and yield losses. While the wheat genotypes showed low disease severity displayed minimum values of AUDPC and yield losses. It was also evident that the susceptible wheat genotypes suffered more yield losses than those of moderately resistant to resistant to stripe rust.

Reaction of commercial wheat genotypes to stripe rust: The reaction of the commercial wheat genotypes to stripe rust at adult plant stage under field conditions is shown in (Tables 2 and 3 ). The fungicide-protected plots remained almost free from stripe rust during the two growing seasons of this study (2013/14and 2014/15).

In 2013/14 growing season, all of the tested wheat genotypes showed different disease severity ranged from $5 \mathrm{MR}$ to $80 \mathrm{~S}$ (Tables 2). The genotypes Sakha 61, Misr 1, Misr 2 and Giza 168 showed the least disease severity (5MR- 20MR), followed by 
Sakha 94, Sids 13, Giza 171 and Shandaweel 1 (10 MS). While, the rest of the tested cvs.exhibited rust severity ranged from $20 \mathrm{MS}-80 \mathrm{~S}$.

In 2014/15 growing season, all of the tested genotypes exhibited susceptible infection type. The cvs. Sakha 61, Sids 13, Misr 1 and Misr2 showed lower rust severity ranged from 10MR- 20MR. While, the genotypes Sakha 69, Sakha 93, Sakha 94, Sids 12, Sids 13, Gimmeiza 9, Gimmeiza 11, Giza 168 and Morocco showed higher rust severity ranged from $10 \mathrm{~S}$ to $90 \mathrm{~S}$. Ashmawy, ( 2005) found that the wheat genotype Sakha 61 was resistant at adult plant stage and has low terminal rust severity $(5 \mathrm{R})$ under heavy stripe rust epidemic and its resistance may be attributed to the presence of the effective gene Yr5. The rust severity of the genotypes Gimmeiza 9, Gimmeiza 11 and Giza 168 was $20 \mathrm{MS}, 30 \mathrm{MS}$ and $20 \mathrm{MR}$ respectively in season 2013/14, while in season2014/15 the rust severity of the same genotypes were 20S, 305 and $40 S$ respectively. This high severity occurred in these genotypes in season 2014/15 may be due to the appearance of new stripe rust race (s). Shahin, (2008) found that the wheat varieties Sakha 69 and Sakha 8 were highly susceptible at both seedling and adult growth stages despite their resistance in previous studies for stripe rust isolates from Sakha 93 and Gemmeiza 9. Also, the wheat genotypes Sakha 69 and Sakha 8 were susceptible at both growth stages Ashmawy, (2010) and this may be due to the widest virulence race in this study. However, they were resistant to Giza 168 and Gemmeiza 10 isolates of stripe rust of wheat both in the seedling and adult plant growth stages Ashmawy, (2010), Khodarahmi, et. al, (2001) Mundt, et al, (1995).

Table 2. Effect of stripe rust infection on yield component of 13 Egyptian wheat genotypes and Morocco genotypes at Sakha agricultural research station during 2013/014.

\begin{tabular}{|c|c|c|c|c|c|c|c|c|}
\hline \multirow{2}{*}{ Genotype } & \multirow{2}{*}{$\begin{array}{l}\text { Final } \\
\text { rust } \\
\text { severity }\end{array}$} & \multirow{2}{*}{ AUDPC } & \multicolumn{3}{|c|}{1000 kernel weight (gm) } & \multicolumn{3}{|c|}{ Plot weight $(\mathrm{kg})$} \\
\hline & & & infected & protected & Losses\% & infected & protected & Losses $\%$ \\
\hline Gemmeiza 9 & $20 \mathrm{MS}$ & 208 & 41.65 & 44.40 & 6.20 & 21.42 & 23.11 & 7.31 \\
\hline Gemmeiza 11 & $30 \mathrm{MS}$ & 380 & 41.83 & 44.55 & 6.20 & 23.21 & 25.25 & 8.07 \\
\hline Sakha 61 & $5 \mathrm{MR}$ & 26 & 38.50 & 39.50 & 2.60 & 13.50 & 14.10 & 4.25 \\
\hline Sakha 69 & $30 \mathrm{~S}$ & 475 & 36.44 & 41.55 & 12.30 & 11.99 & 14.15 & 15.26 \\
\hline Sakha 93 & $30 \mathrm{~s}$ & 475 & 36.86 & 40.95 & 9.90 & 18.99 & 21.3 & 10.84 \\
\hline Sakha 94 & $10 \mathrm{MS}$ & 160 & 38.68 & 40.88 & 5.38 & 20.10 & 21.45 & 6.29 \\
\hline Sids 12 & $40 \mathrm{~S}$ & 750 & 38.60 & 43.58 & 11.50 & 21.30 & 24.60 & 13.41 \\
\hline Sids 13 & $10 \mathrm{MS}$ & 168 & 40.10 & 41.60 & 3.33 & 22.13 & 23.95 & 7.59 \\
\hline Misr 1 & $5 \mathrm{MR}$ & 26 & 40.55 & 42.58 & 2.60 & 22.12 & 23.14 & 4.40 \\
\hline Misr 2 & $5 \mathrm{MR}$ & 26 & 41.38 & 42.99 & 3.74 & 22.55 & 23.56 & 4.28 \\
\hline Giza 168 & $20 \mathrm{MR}$ & 265 & 42.12 & 43.94 & 4.32 & 23.02 & 24.45 & 5.84 \\
\hline Giza 171 & $10 \mathrm{MS}$ & 168 & 41.15 & 42.33 & 2.8 & 23.42 & 24.54 & 4.56 \\
\hline Shandaweel 1 & $10 \mathrm{MR}$ & 84 & 41.34 & 42.93 & 3.70 & 22.65 & 23.56 & 3.86 \\
\hline Morocco & $80 S$ & 1750 & 30.23 & 39.45 & 30.49 & 10.31 & 14.98 & 31.17 \\
\hline LSD & & & & 0644 & & & 0.0 & 488 \\
\hline
\end{tabular}


Table 3. Effect of stripe rust infection on yield component of 13 Egyptian wheat genotypes and Morocco genotype at Sakha agricultural research station during 2014/015.

\begin{tabular}{|c|c|c|c|c|c|c|c|c|}
\hline \multirow{2}{*}{ Genotype } & \multirow{2}{*}{$\begin{array}{l}\text { Final } \\
\text { rust } \\
\text { severity }\end{array}$} & \multirow{2}{*}{ AUDPC } & \multicolumn{3}{|c|}{1000 kernel weight (gm) } & \multicolumn{3}{|c|}{ Plot weight $(\mathrm{kg})$} \\
\hline & & & infected & protected & Losses $\%$ & infected & protected & Losses $\%$ \\
\hline Gemmeiza 9 & $40 \mathrm{~S}$ & 625 & 40.60 & 44.40 & 8.55 & 20.42 & 23.10 & 11.60 \\
\hline Gemmeiza 11 & $50 \mathrm{~S}$ & 900 & 40.38 & 44.60 & 9.46 & 21.61 & 25.25 & 14.41 \\
\hline Sakha 61 & $20 \mathrm{MR}$ & 26 & 39.50 & 40.50 & 2.46 & 13.50 & 14.22 & 5.06 \\
\hline Sakha 69 & $70 \mathrm{~S}$ & 1100 & 36.18 & 41.99 & 13.83 & 11.25 & 14.25 & 21.05 \\
\hline Sakha 93 & $60 \mathrm{~S}$ & 950 & 36.60 & 40.90 & 10.51 & 18.12 & 21.3 & 14.92 \\
\hline Sakha 94 & $10 \mathrm{~S}$ & 128 & 38.45 & 39.90 & 3.63 & 20.10 & 21.45 & 6.29 \\
\hline Sids 12 & $60 \mathrm{~S}$ & 950 & 39.60 & 44.50 & 11.01 & 20.12 & 24.60 & 18.21 \\
\hline Sids 13 & $20 \mathrm{~S}$ & 260 & 40.10 & 41.60 & 3.60 & 22.13 & 23.95 & 7.59 \\
\hline Misr 1 & $10 \mathrm{MR}$ & 84 & 40.25 & 42.10 & 4.39 & 22.12 & 23.14 & 4.40 \\
\hline Misr 2 & $10 \mathrm{MR}$ & 84 & 41.34 & 42.93 & 3.70 & 22.65 & 23.56 & 3.86 \\
\hline Giza 168 & $40 S$ & 750 & 40.66 & 43.95 & 8.09 & 22.01 & 24.25 & 9.23 \\
\hline Gisa 171 & $20 S$ & 310 & 40.60 & 42.10 & 3.69 & 22.42 & 24.54 & 8.63 \\
\hline Shandaweel 1 & $5 \mathrm{~S}$ & 105 & 41.04 & 42.97 & 4.70 & 22.35 & 23.66 & 5.83 \\
\hline Morocco & $90 \mathrm{~S}$ & 2050 & 30.05 & 39.89 & 32.74 & 10.01 & 15.99 & 37.39 \\
\hline LSD & & & & 0828 & & & 22 & \\
\hline
\end{tabular}

Area under disease progress curve (AUDPC): Data in Tables 2, 3 and Figure 1 indicates that AUDPC run in a parallel line with disease severity. In 2013/14 growing season, the results obtained showed that the low values of AUDPC were observed on cvs. Sakha 61 , Misr 1, Misr 2 and Sakha 94 (26, 26, 26 and 160). Whereas, cvs. Sids 13, Giza171, Gemmeiza 9, Giza 168, Gemmeiza 11, Sakha 93, Sakha 69, Sids 12 and Morocco exhibited highest values of AUDPC i.e. 168, 168, 208, 265, 380, 475, 475, 750 and 1750 respectively. According to these results in season 2013/14, the results obtained showed that the low values of AUDPC were observed on cvs. Sakha 61, Sakha 94 Misr 1, Misr 2 and Sids 13 (26, 128, 160, 160 and 168). Whereas, cvs. Giza171, Gemmeiza 9, Giza 168 Giza 168 Gemmeiza 11, , Sakha
93, Sids 12, Sakha 69 and Morocco exhibited highest values of AUDPC i.e. 310, $625,750,900,950,950,1100,2050$, respectively. the wheat genotypes were classified into two main groups, the first group included the fast rusting wheat genotypes that displayed the highest values of AUDPC (more than 200) i.e. Gemmeiza 9, Gemmeiza 11, Giza 168, Sakha 93, Sakha 69 and Sids 12. The second group included the slow rusting wheat genotypes that displayed the lowest values of AUDPC (less than 200) i.e. Sakha 61, Sakha 94 Misr 1, Misr 2 and Sids 13. In 2014/15 growing season, data in Tables 2 and 3 indicates that the cvs. Gemmeiza 9, Giza 168, Gemmeiza 11, Sakha 93, Sids 12, Sakha 69 and Morocco showed the highest values of AUDPC (fast rusting) i.e. 625, 750, 900, 950, 950, 1100 and 2050 respectively. 
Omar, Hend abd el- naby(2015) found that the wheat cv. Giza 168, Misr 1 and Misr2 showed low level of AUDPC, while the wheat genotypes Sakha 93 and Gemmeiza 11 showed high levels of AUDPC to stripe rust. Kurt, (2002) Omara, (2009), Shahin,(2008).

Grain yield and yield losses: The 1000 kernel weight and grain yield per plot differences between protected and infected wheat genotypes due to the differences in the level of disease severity of stripe rust as shown in Tables 2 and 3 . In $2013 / 14$, the loss percent of the 1000 kernel weight ranged from 2.69 to $13.29 \%$. The cvs. Sakha 93, Sids 12, Sakha 69 and Morocco gave the highest percent of loss of 1000 kernel weight $(9.98,11.42,12.29$ and $30.90 \%$ respectively) compared to the other genotypes. In 2014/15, the loss percent in the 1000 kernel weight ranged from 2.46 to $13.83 \%$. The cvs. Gemmeiza 11, Sakha 93, Sids 12 and Sakha 69 gave the highest values of loss present of the 1000 kernel weight $(9.46,10.51,11.01$ and $13.83 \%$, respectively) followed by cvs. Gemmeiza 9 , Giza 168, Misr 1, Misr 2, Sakha 61, Sakha 94 and Giza 171.The loss percent of gran yield per plot in 2013/14 ranged from 4.25 to $15.26 \%$. The cvs. Sakha 93, Sids 12 and Sakha 69 showed the highest values of loss percent of gran yield per plot $(10.84,13.41$ and $15.26 \%$ ) compared to the other genotypes. In 2014/15, the loss percent of gran yield per plot ranged from 3.94 to 37.39 $\%$. The cvs. Gemmeiza 11, Sakha 93, Sids 12, Sakha 69 and Morocco gave the highest values of loss percent of yield per plot (14.41, 14.92, 18.21, 21.05 and $37.39 \%$, respectively), while, the cvs. Sakha 61, Sakha 94, Misr 1, Misr 2, Giza 171 showed the lowest values of loss percent of yield per plot. This trend is in aharmony with losses reported in previous studies obtained by (Abu El- Naga, et al.,1999, Sing, et al., 2005 and Ochoa and Parlevliet 2007) reported that yield loss was correlated strongly with area under disease progress curve, which means that high levels of partial resistance are needed to prevent significant yield loss.

This study showed that stripe rust reduced yield respective of the type and level of resistance possessed by the cultivars (El- Daoudi et. al., 1996). The effect of rust on grain yield may be due to the energy expenditure in plant defense mechanisms rather than for growth and grain information (Smedegaard-Petersen and Tolstrup, 1985). Moreover, the tissue damage caused by hypersensitive reactions also contributes to yield reduction (Khannaet al., 2005). The present study showed that the infection with stripe rust can severely reduce grain yield on susceptible cultivars. Therefore, growing slow rusting genotypes will reduce the loss percent in grain yieldVechet andTvaruzek (2002)

\section{Association between AUDPC and loss in the 1000 kernel weight and loss in grain yield/plot: The} association of the 1000 kernel weight and loss percent of grain yield/ plot and AUDPC was determined through regression analysis during 2013/14 and 2014/15 growing seasons. Positive relation between AUDPC and loss percent of 1000 kernel weight during the two growing seasons $\left(R^{2}=0.492\right.$ and 0.783 respectively) (Fig. 1). Also, regression analysis revealed a significant linear relationship $\left(R^{2}=0.959\right.$ and 0.9447$)$ between loss percent of grain yield/ plot and AUDPC. On overall basis cultivars with maximum disease severity had lower mean grain yield and vice versa (Shaneret al., 1978). Ochoa and Parlevliet (2007) reported that yield loss was correlated strongly with AUDPC found that a significant correlation between mean disease severity and percentage loss for 1000-kernel and grain yield/plant. 

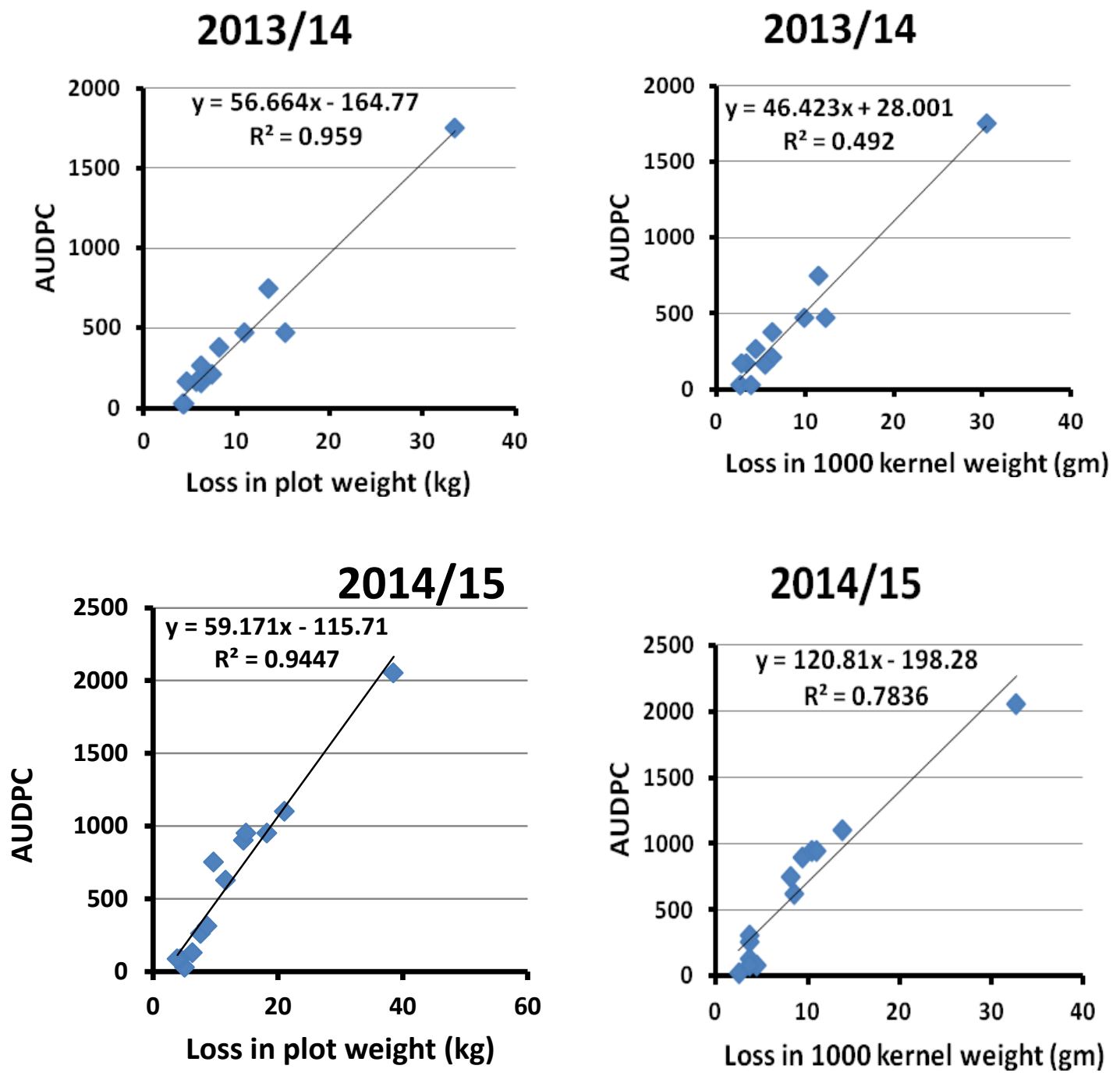

Fig. (1): Association between AUDPC with loss percent of1000 kernel weight and loss in grain yield/ plot for 13 Egyptian bread wheat genotypes and Morocco varieties tested during 2013/14 and 2014/15 growing seasons.

\section{REFERENCES}

Abd El- Hak, T. M., D. M. Stewart and A. H.Kamel (1972). The current rust situation in the Near East countries.Regional wheat workshop. Beirut Lebanon, 11-15:81-90.

Abu El-Naga, S.A., M. M.Khalifa, W. A. Youssef and H. A. Abd El-Latif (1998). Stripe rust situation during the period (1994-1996) with special reference to designating genes conferring resistance in certain Egyptian wheat germplasm.J. Agric. Sci. Mansoura Univ. 23:1127-1136.

Abu El-Naga, S. A., M. M. Khalifa, OmaimaAlaa El-Dien, W. A. Youssef and I. A. Embaby (1999). Effect of striperust Puccinia striiformis West infection on grain yield in certain wheat cvs and control application in 
Egypt. during (1996/1997) J. Agric. Sci. MonsouraUniv; 24- (10) 52285308.

Abu El-Naga, S. A., M. M.Khalifa, S. Sherif, W. A. Youssef, Y. H.ElDaoudi and I. Shafik (2001). Virulence of wheat stripe rust pathotypes identified in Egypt during 1999/2000 and sources of résistance. First Regional Yellow Rust Conference for Central \& West Asia and North Africa 8-14 May, $\mathrm{SPH}$, Karj, Iran.

Ashmawy, M. A. (2005). Studies on stripe rust of wheat in Egypt. Msc Thesis, Agricultural Botany Department Faculty of Agriculture , Minufiya University Shebin ELkom.

Ashmawy, M. A. (2010). Advanced Studies on stripe rust disease of wheat in Egypt. Ph. Thesis, Agricultural Botany Department Faculty of Agriculture, Minufiya University Shebin ELkom.

Chen, X. M. and L.Penman (2005). Stripe rust epidemic and races of Pucciniastriiformis in the United States in 2004. Phytopathology 95, S19.

Colpauzos, J., A.P. Roelfs, M.E. Madson, F.B. Martin and R.D. Wilconxson (1976). A new model to measure yield losses caused by stem rust in spring wheat. Agric. Exp. Sta. Univ. Minnesota, Tech. Bull. 307:1-23.

Danial, D. L., R. W. Stubbs and J. E. Parleylit (1994). Evolution of virulence patterns in yellow rust races and its implication for breeding for resistance in wheat in Kenya. Euphytica 1994, 80:3 165 - 170; 19 ref.

El-Daoudi, Y. H., Ikhlas Shafik, E. H.; Ghamem; S. A. Abu El-Naga, S. O. Sherif, M. M. O. Khalifa, R. A. Mitkees and A .A. Bassiouni (1996).
Stripe rust occurrence in Egypt and assessment of grain yield loss in 1995. Proc. Du Symposium Regional Sur les Maladies des Ceraleset des Legumineuses Alimentaries 11-14 November, 1996, Rabat, Maroc.

Hassan, G. (2004). Diallel analysis of some important parameters in wheat (Triticum aestivum L) under irrigated and rain fed conditions. Ph.D. thesis submitted to NWFP Agricultural University Peshawar, Pakistan.

Hong, M.A. and R. P. Singh (1996). Contribution of adult plant resistance gene $\mathrm{Yr} 18$ in protecting wheat from yellow rust. Plant Disease 1-66-69.

Johnson, R. (1988). Durable resistance to yellow (stripe) rust in wheat and its implications in plant breeding. In 'Breeding Strategies for Resistance to the Rusts of Wheat'.(Eds NW Simmonds and S Rajaram.) pp. 6375. (CIMMYT: Mexico.)

Khanna, R., UK, Bansal and R.G. Saini (2005). Genetics of adult plant stripe rust resistance in CSP44 a selection from Aust wheat. J. of Genet, 841, 337- 340.

Khodarahmi, M., M. Ghannadha, A. Saidi, M. Torabi and G. $H$. Karimzadeh (2001). Evaluation of resistance components to three races of Puccinia striiformis in wheat genotypes. First Regional Yellow Rust Conference for Central \& West Asia and North Africa 8-14 May., $\mathrm{SPH}$, Karaj, Iran

Kurt, S. (2002). Screening of wheat cultivars for resistance to stripe rust and leaf blotch in Turkey.Crop protection. 21:6, 495-500.

Mundt, C. C., L. S. Brophy and M. S. Schmitt (1995). Disease severity and yield of pure- line wheat cultivars and mixture in the presence of eyespot, yellow rust, and their combination. 
Plant Pathology (1995) 44, $173 \quad-$ 182.

Ochoa, J. and J.E. Parlevliet (2007).Effect of partial resistance to barley leaf rust, Puccinia hordeion the yield of three barley cultivars. Euphytica.153:309-312.

Omara, R. I. (2009).Studies on wheat yellow rust disease in Egypt. Msc Thesis, Agricultural Botany Department Faculty of Agriculture, Kafer El-Sheik University, Kafer ElSheik.

Omar, M. Hend abd el-naby (2015). Studies on stripe rust disease of wheat in Egypt. Ph. Thesis, Agricultural Botany Department Faculty of Agriculture, Mansoura University Mansoura.

Pandey, H.N., T. C. M. Menon and M. V. Rao (1989).A simple formula for calculating area under disease progress curve. Rachis vol.8.no.2:3839.

Peterson, R.F.; A.B. Compbell and A.E. Hamah (1948).A diagrammatic scale for estimating rust intensity on leaves and stems of cereal Can. J. Res. 60.496-500.

Roelfs, A.P., R.P. Singh and E.E. Saari (1992). Rust diseases of wheat: Concepts and methods of disease management. CIMMYT, Mexico, D.F.

Shaner, G., H.W. Ohm and R.E. Finnay (1978). Response of susceptibility and slow leaf rusting of wheat's to infection by Puccinia recondita. Phytopathol. 68:47475.

Shahin, A. M. (2008). Further studies on the Nature of resistance of wheat yellow rust in Egypt .Ph D Thesis, Faculty of Agriculture Kefr El sheikh University Kefr EL -Sheikh -Egypt.
Singh, RP. (2002). Bread wheat: Improvement and Production. Rome: Food and Agricultural organization of the United Nations.

Singh, R.P., Huerta Espino, J. andH.M.William (2005). Genetics and breeding for durable resistance to leaf and stripe rusts in wheat. Turkisk J. Agric. And Forestry. 29(2):121-127.

Smedegaard-Petersen, V. and K. Tolstrup (1985).The limiting effect of disease resistance on yield .Annual Review Phytopathol.23:475-490.

Snedecor, G.W. (1957). Statistical Methods, 5th eds. lowa State College Press, Ames, lowa.Wang, Z.L.; L.H. Li; Z.H. He; X. Duan; Y.L. Zhou; X.M. Chen; M. Lillemo; R.P. Singh; H. Wang and H. Xia XC (2005): Seedling and adult plant resistance to powdery mildew in Chinese bread wheat cultivars and lines. Plant Dis. 89:457-463.

Stubbs, R.W. (1985). Stripe rust In The cereal Rust: Disease, Epidemiology and control Bushnell WR, Roelfs AP (eds), Academic press, London.

Stubbs, R.W (1988). Pathogenicity analysis of yellow (stripe) rust of wheat its significance in a global context breeding strategies for persistence to the rust of wheat N,W. Simmonds and S. Rajaram (CIMMYT) ISBN 96-127

Vechet, L. and I. Tvaruzek (2001). Response of winter wheat varieties to Puccinia striiformis f-sp tritici sustainablesystems-of -cereal-crop protection against Fungal diseases as the way of reduction of toxin occurrence in food webs -A. healthy-cereals-proceedings, kromeriz,-Czech-Republic,2-6-Juiy-2001. 248-250. 
تقير الخسائر بمرض الصدأ الاصفر في بعض اصناف القمح في مصر

\author{
مداوح عبد المنعم عشماوي ، خالا رجب الامرداش
}

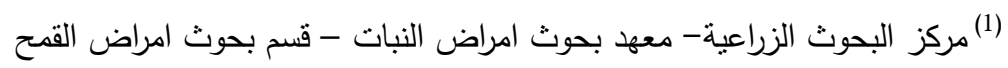
(2) مركز البحوث الزراعية - معهد بحوث المحاصيل الحقلية - قسم بحوث القمح

\title{
الملخص العربي
}

بعثبر مرض الصدأ الأصفر من اهم امراض القحح في مصر وعلي مستوي العالم. تم تصميم تجربة الخسائر

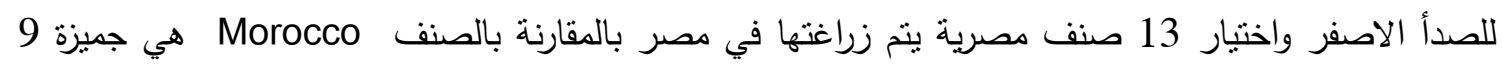

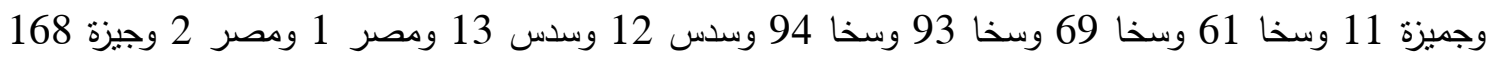

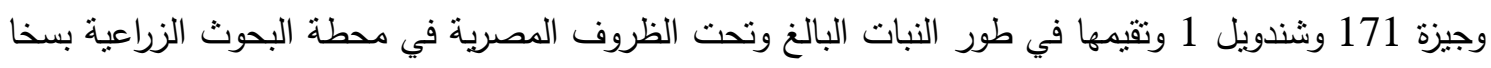

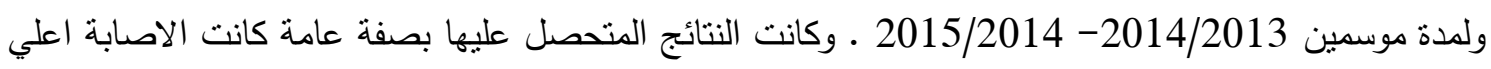

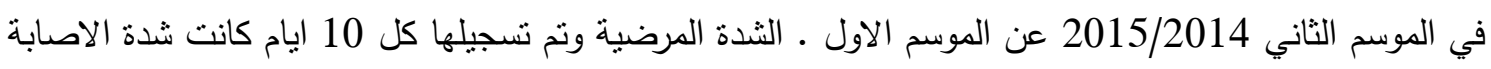

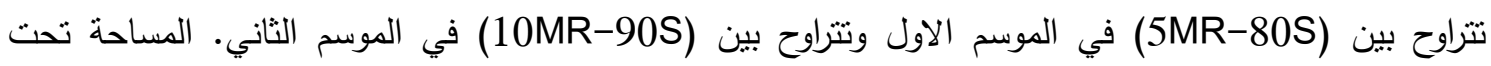

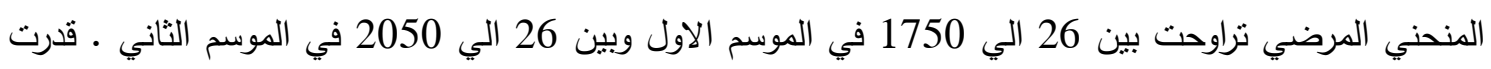

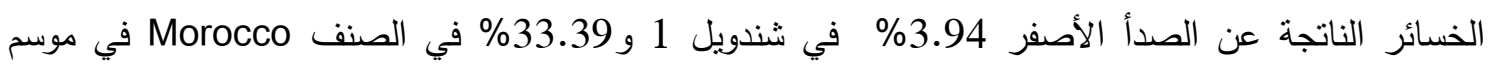

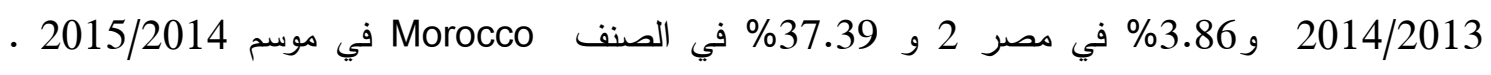

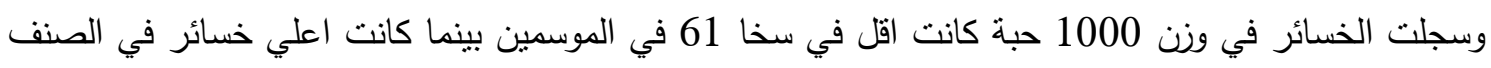
30.49 Morocco

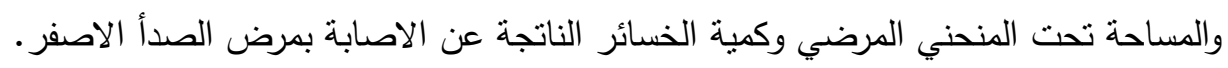

البريد الالكترونى

E-mail:mujareg@gmail.com
موقع المجلة

Mujareg.blogspot.com

http://www.mujar.net 
